\title{
LIGAS: \\ KOREOGRAFI TENTANG PERJUANGAN PETANI TANAH TAMBANG DI BELITUNG
}

\author{
Bella Asmanabillah \\ Jurusan Tari, Fakultas Seni Pertunjukan ISI Yoogyakarta \\ E-mail: bellaasmanabillahh@gmail.com
}

\begin{abstract}
ABSTRAK
"Ligas" merupakan koreografi kelompok yang terispirasi dari keadaan agraris masa kini di daerah Belitung. Petani ladang terlihat sangat miris, karena gagal panen yang terjadi di tahun 2019 akibat kemarau dan pencemaran lingkungan akibat pertambangan. Karya ini merupakan pengembangan dari budaya Melayu Belitung, yang mengangkatdilematis perjuangan hidup petani dalam mengais bulir-bulir padi jenis Gogo. Tipe karya garapan ini adalah tari Dramatik, dengan mode simbolis. Karya ini terdiri, introduksi yang menggambarkan situasi bumi yang subur hingga menjadi gersang. Adegan 1, menggambarkan aktivitas bercocok tanam di ladang. Adegan 2, terjadi konflik lahan pertanian menjadi rusak akibat pertambangan. Adegan 3, petani berusaha memperbaiki keadan dengan sekuat tenaga. Ending, seluruh penari melakukan pesta panen padi sebagai rasa syukur dengan menari Sepen secara berpasang-pasangan.Dalam karya ini menggunakan pendekatan koreografi lingkungan yang terdiri dari sensasi ketubuhan, sensasi emosi, sensasi imaji, dan ritus ekspresi. Iringan musik dalam karya ini merupakan hasil dari respon konsep tari yang berangkat dari idiom musik Melayu Belitung. Visual dalam karya ini lebih menonjolkan aktivitas petani berladang, hingga perjuangan petani dalam menghadapi kerusakan lingkungan. Kemudian para petani tidak melupakan tradisi setiap tahunnya yaitu pesta panen padi yang menari secara berpasang-pasangan.
\end{abstract}

Kata Kunci: Berladang, Pertambangan, Tari Sepen

\begin{abstract}
"Ligas" was a group choreography that is danced by male and female dancers. This work was inspired by stylist's observations of the current agrarian situation in the Belitung area. Farmers looked very concerned because the harvest failure that occurred in 2019 due to drought and environmental pollution that occurred due to mining activities. Contemporary dance arose from the
\end{abstract}


Belitung Malay culture which raised the dilemma of farmers' life struggles in scavenging grains of Gogo rice. This type of work was a Dramatic dance, with a symbolic fashion. This work consists of an introduction that illustrated the situation of a fertile earth to become arid. Scene 1, described farming activities in the field. Scene 2, a conflict in agricultural land became damaged due to mining. Scene 3, the farmer tried to improve his condition with all his strength. Ending, all dancers hold a rice harvest party as a thanksgiving by dancing in half in pairs. In this work an environmental choreography approach consisting of bodily sensations, emotional sensations, image sensations, and expression rites. The musical accompaniment in this work was the result of the response to the dance concept derived from the Belitung Malay musical idiom. Visuals in this work highlight the activities of farmers in farming, to farmers' struggles in dealing with environmental damage. Then the farmers did not forget the tradition every year, namely the rice harvest party that dances in pairs. Keywords: Farming, Mining, Sepen Dance

\section{PENDAHULUAN}

\section{A. Latar Belakang Penciptaan}

Karya Ligas adalah karya tari yang terinspirasi dari pengamatan terhadap keadaan agraris masa kini di Provinsi Bangka

Belitung. "Ligas" merupakan bahasa Belitung yang berarti sebuah usaha sekuat tenaga sebelum kehilangan semuanya. Penata melihat para petani yang sedang bercocok tanam di ladang dengan penuh kerja keras. Mereka berusaha dari mengolah tanah hingga merawat padi agar tetap tumbuh dengan baik.

Masyarakat tradisional Belitung mulanya bertempat tinggal di bagian pesisir pulau Belitung, kemudian masuk ke daerah pedalaman daratan untuk mencari sumber makanan (Adithya, 2016:1-2) Mereka hidup berkelompok memanfaatkan lahan yang ada untuk diolah, membuka ladang demi mencari sumber makan. Mereka menanam padi jenis Gogo yang dipanen setiap satu tahun sekali, karena padi ini tumbuh tidak seperti padi sawah yang memiliki pengairan khusus (Wiranto,2019).

Pada musim tanam padi periode meijuni 2019, dari 126 hektar lahan padi, sejumlah 112 hektar mengalami gagal panen akibat kekeringan yang terjadi di Dusun Danau Nujau Kecamatan Gantung Kabupaten Belitung Timur. Petani yang bernama pak Subagio mengatakan bahwa selama 40 tahun beliau mengolah sawah tersebut baru tahun ini mengalami kekeringan hingga dinyatakan 
gagal panen. Kekeringan ini merupakan kekeringan terpanjang hingga dua bulan lebih.

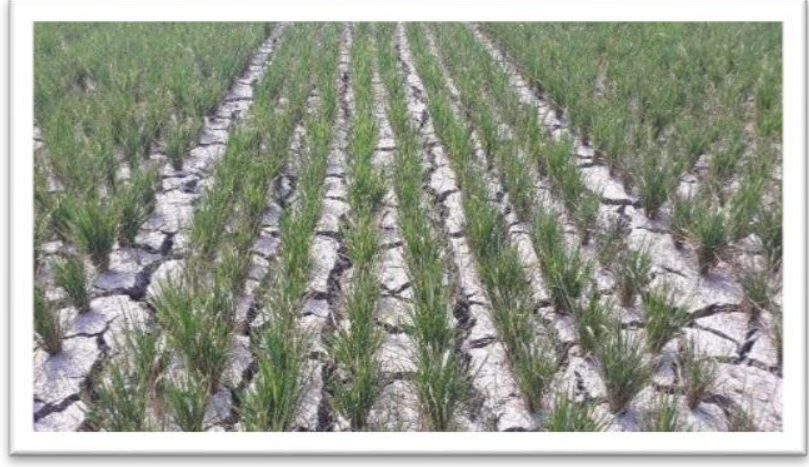

Gambar 1: Gagal panen padi di Babel karena kekeringan

(Sumber:https://www.google.com/amp/s/bangka.tribunn e ws.com/amp/2019/09/13/gagal-panen-padi-mencapairp2-m-klaim-asuransi-petani).

Permasalahan kontekstual agraria yang ada di daerah Bangka-Belitung adalah pertanian yang kehilangan lahan akibat pertambangan yang mencemarkan lingkungan.

Berdasarkan kondisi tersebut sangat sulit masyarakat untuk kembali bercocok tanam. Adapun kerusakan lahan pasca tambang berpengaruh pada fisik lahan serta kimia tanah yang tercemar. Sehingga letak lokasi ladang padi pun berada di sebelah tambang timah (Ismi, 2019).

Survey dari Dinas Pertanian Provinsi Kepulauan Bangka Belitung mengatakan bahwa lahan pertanian semakin kritis karena maraknya pembukaan lahan besar-besaran untuk pertambangan. Dari pertambangan tersebut banyak sekali dampak bagi lingkungan. Contohnya adalah tanah yang menjadi tidak subur atau tidak bisa ditanami, karena sudah tercemar dari bahan kimia yang beracun hingga, mengubah komposisi kimia tanah itu sendiri. Kemudian kondisi air juga turut tercemar akibat air bekas tambang mengalir ke sungai, hingga menjadi keruh dan kotor. Air bekas tambang tersebut mengandung logam berat yang dapat merembes ke sistem air tanah dan dapat mencemari air tanah permukiman sekitar.

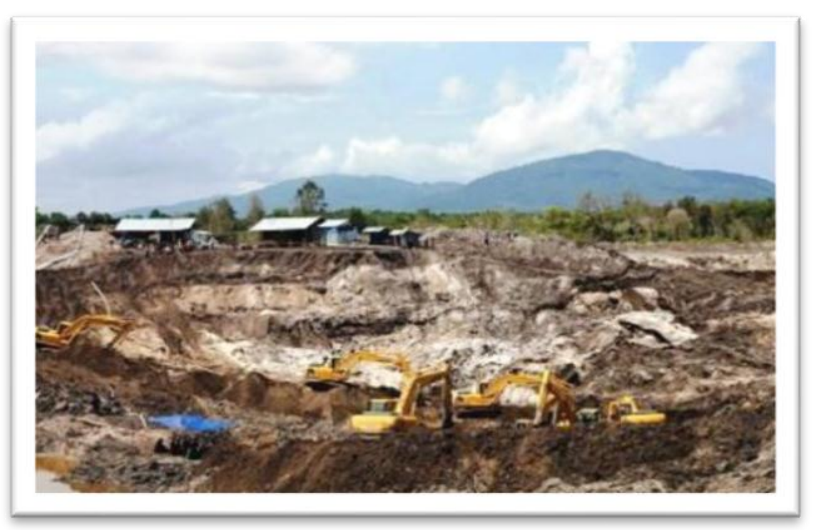

Gambar 2: Kondisi Pertambangan liar yang merusak Lingkungan di Bangka Belitung (Sumber: https://m.tribunnews.com/regional/2014/02/19/pold babel-akan-berantas-penambang-liar

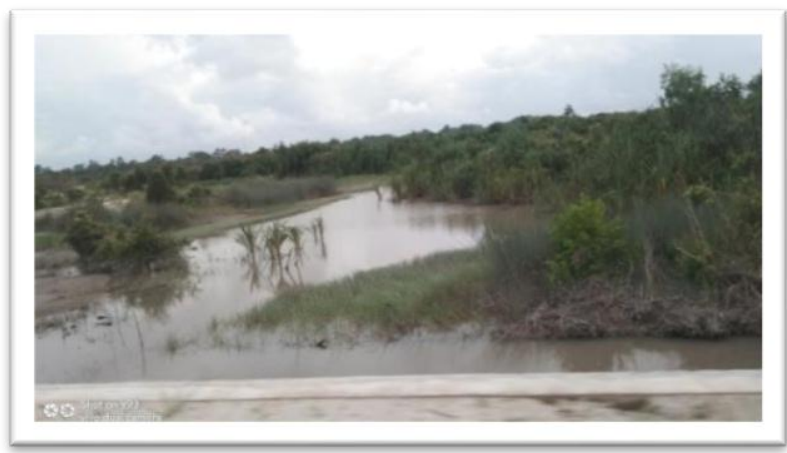

Gambar 3: Kondisi air yang tercemar akibat pertambangan (Foto: Bella, 4 Jan 2020).

Walaupun gagal panen, petani Belitung tetap saja menggelar Upacara Adat yaitu Marastahon. Marastahon adalah Upacara adat yang dilakukan petani Belitung sebagai 
JOGED: Jurnal Seni Tari

p-ISSN 1858-3989 | e-ISSN 2655-3171

wujud rasa syukur kepada Allah SWT, yang telah melewati musim panen padi, serta meminta keselamatan warga dan keberhasilan panen di tahun yang akan datang.

Salah satu hiburan yang terdapat di acara Marastahon adalah tari Sepen. Tari ini ditarikan secara berpasangan oleh penari lakilaki dan perempuan berjumlah genap.

Spesifikasi dari tari sepen adalah kaisan kaki, dan tepuk tangan. Unsur gerak tersebut selalu hadir dari awal tarian hingga akhir tarian. (Ayu, 2015).

Gerak kais kaki menyimbolkan aktivitas bekerja untuk mencari rezeki atau7 mencari makan dan juga simbol dari gerak membersihkan padi. Masyarakat Belitung percaya bahwa tepuk tangan serta loncat menyimbolkan ungkapan rasa kegembiraan.

Dalam seni pertunjukan khususnya karya tari sangat banyak menghadirkan simbol-simbol yang akan mewakili perasaan penata tari, untuk divisualkanhingga konsep yang sudah ditata akan tersampaikan dengan baik dan penuh makna ke hadapan penonton.

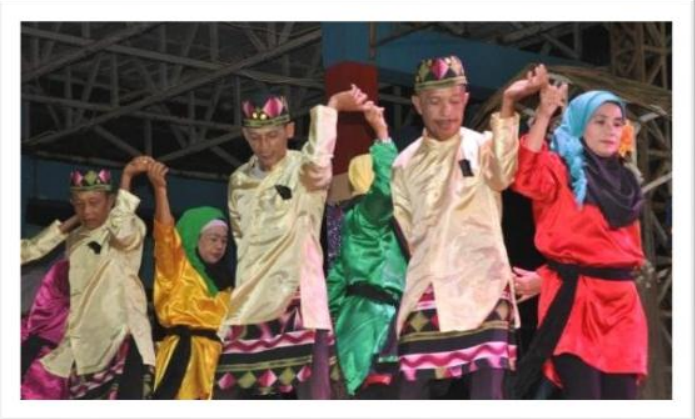

Gambar 4 : Tari Sepen Tari Berpasangan (sumber: https://disbudpar.belitungtimurkab.go.iddiungggah 10 Juli 2017)

Berikut ini penjelasan simbol menurut pandangan para ahli:

Karya seni sebagai simbol, atau katagori tempat yang dibuat oleh manusia secara sengaja, di dalamnya termuat baik simbol manusuka (arbritrary symbol) maupun simbol ikonik (iconic symbol). Simbolsimbol dalam kesenian adalah simbol ekspresi, yang berkaitan dengan perasaan atau emosi manusia, yang digunakan ketika mereka terlibat dalam kegiatan atau komunikasi seni (Barger, 1984:7). ${ }^{1}$

Susanne K. Langer mengungkapkan bahwa gerak-gerak ekspresi ialah gerak yang indah, yang dapat menggetarkan perasaan manusia. Sedangkan gerak indah ialah gerak yang distiril dan mengandung ritme tertentu.

${ }^{1}$ Rina Martiara dan Budi Astuti, Analisis Struktural Sebuah Metode penelitian Tari, Yogyakarta: Badan Penerbit ISI Yogyakarta, 2018, 17. 
LIGAS: KOREOGRAFI TENTANG PERJUANGAN PETANI TANAH TAMBANG DI BELITUNG

\section{PEMBAHASAN}

\section{A. Kerangka Dasar Pemikiran}

Tema karya tari Ligas, yaitu "Perjuangan Petani" sangat jelas terlihat dari setiap situasi yang selalu mengarah dengan lingkungan Bumi Belitung. Situasi yang miris akibat kurang suburnya tanah yang ada di Belitung membuat petani harus berusaha lebih keras untuk bercocok tanam. Hal ini digambarkan pada aktivitas petani ladang yang sedang bercocok tanam. Kemudian menggambarkan saat bumi Belitung masih kesuburan hingga terjadi suasana kemarau dan kondisi kerusakan lingkungan akibat pertambangan. Kebersamaan dan kegotong-royongan masyarakat dalam bekerja atau mengais rezeki di ladang menjadi inspirasi dalam karya tari ini.

Landasan penciptaan karya tari ini menggunakan gerak mengais yang bersumber dari gerak spesifik tari Sepen, yang menyimbolkan mencari rezeki, dan gerak nugal dengan properti igal yang menggambarkan petani sedang melubangi tanah. Teknik gerak yang digunakan seperti menghentak, dan mengalir. Untuk mewujudkan karya, maka ditentukan hal di bawah ibi dengan argumennya:

1. Memilih penari berjenis kelamin laki-laki dan perempuan, untuk menyampaikan makna kesuburan.
JOGED: Jurnal Seni Tari p-ISSN 1858-3989 | e-ISSN 2655-3171

2. Memilih penari yang berjumlah genap, karena kesenian Besepen dilakukan secara berpasang-pasangan dan selalu genap.

3. Menggunakan properti igal atau kayu untuk melubangi tanah ketika hendak berladang.

4. Menggunakan jaring-jaring hitam atau pranet sebagai pendukung setting lingkungan yang tercemar.

5. Memilih iringan musik yang berangkat dari idiom musik Melayu Belitong, yang dimainkan secara langsung hingga memudahkan merespons gerak.

\section{B. Konsep Dasar Tari}

\section{Rangsang Tari}

Rangsang menjadi hal dasar yang menggerakkan fikir dan fisik untuk mencipta gerak maupun tarian. Rangsang bagi komposisi tari dapat berupa auditif, visual, gagasan, rabaan atau kinestetik (Smith, 1985:20). Karya ini mengarah pada rangsang ideasional dan kinestetik.

Rangsang ide timbul dari pengalaman melihat secara langsung acara Marastahun yang menghadirkan tari Sepen, yang merupakan tarian berpasangan sebagai ungkapan kegembiraan masyarakat saat merayakan panen padi. Namun tidak hanya sebagai ungkapan kebahagian, tetapi juga perjuangan petani dalam mencapai 
JOGED: Jurnal Seni Tari

p-ISSN 1858-3989 | e-ISSN 2655-3171

keberhasilan panen padi yang tidaklah mudah.

Petani dihadapkan dengan kondisi tanah yang kurang subur, lahan pertanian yang kritis akibat pertambangan yang makin meluas, curah hujan yang tidak menentu, membuat petani harus berusaha keras untuk merawat padi-padi tersebut agar tumbuh dan berkembang sampai bisa dipanen. Pada tahun 2019 pun terjadi kemarau yang panjang hingga banyak petani yang mengalami gagal panen. Kedua situasi ini yang menjadi ide penciptaam karya tari ini.

Rangsang kinestetik yang diambil adalah gerak kais, dan gerak tepuk tangan pada tari Sepen. Gerak dasar ini diolah dan dikembangkan dari aspek koreografinnya yaitu ruang, waktu, dan tenaga.

\section{Tema Tari}

Tema dari kaya Ligas adalah "Perjuangan Petani", yang dimaksud sebagai kerja keras petani dalam menghadapi cuaca yang buruk hingga keadaan tanah yang tidak subur. Saat ini kondisi bumi Belitung mengalami mirisan akibat pertanian dan pertambangan hidup berdampingan tetapi bertentangan. Kondisi tersebut sangat merugikan di bidang pertanian, akibat pertambangan tanah menjadi tidak subur, dan lahan yang subur dibabat habis hingga lahan pertanian menjadi kritis.
LIGAS: KOREOGRAFI TENTANG PERJUANGAN PETANI TANAH TAMBANG DI BELITUNG

3. Judul Tari

Judul adalah salah satu komponen yang sangat penting dalam sebuah karya. Judul karya tari ini menggunakan bahasa daerah Belitung yaitu "Ligas", yang memiliki arti berusaha sekuat tenaga sebelum kehilangan semuanya.

\section{Bentuk dan Cara Ungkap}

Pada karya ini menggunakan tipe tari Dramatik yang mengandung arti bahwa gagasan yang dikomunikasikan sangat kuat, penuh daya pikat, dinamis, banyak ketegangan, dan mungkin melibatkan orang lain. Tari dramatik akan memusatkan perhatian pada sebuah kejadian atau suasana yang tidak menggelarkan cerita (Smith, 1985:27). Kejadian-kejadian yang dialami petani akan diwujudkan bermula dari awal bercocok tanam dengan suasana tenang, lalu mengalami kegagalan dengan emosi yang tegang dan miris, dan akhirnya merayakan pesta panen padi dengan kegembiraan.

Jacqueline Smith mengatakan bahwa mode penyajian tari ada dua macam yaitu secara representasional dan simbolis. Pada karya Ligas menggunakan mode penyajian simbolis. Mode simbolis artinya menghadirkan tanda tertentu atau tanda orisinil, serta dari aspek lainnya unik dan tidak nyata (Smith, 1985:29). Adapun urutan penyajian Ligas sebagai berikut: 
LIGAS: KOREOGRAFI TENTANG PERJUANGAN PETANI TANAH TAMBANG DI BELITUNG

a. Introduksi

Penari laki-laki dan perempuan, menari secara berpasangan yang menyimbolkan kesuburan. Keadaan awal yang subur kemudian berubah menjadi kerusakan.

\section{b. Adegan 1}

Adegan ini menghadirkan 8 penari membawa igal, dari membuka lahan kemudian nugal sampai menyamai benih padi. Di bagian ini gerak yang dilakukan penari adalah pengembangan gerak kais dengan olah properti igal.

\section{c. Adegan 2}

Adegan 2 terjadi konflik, yang ditandai dengan jatuhnya paranet dari atas hingga menutupi petani yang sedang bertani. Penata menggambarkan terjadilah kerusakan lingkungan dari segi tanah maupun air yang berdampak ke pertanian.

\section{d. Adegan 3}

Perlahan suasana berubah membaik dengan usaha yang kuat terlihat dilakukan oleh panari untuk menggambarkan bahwa para petani Belitung bisa membalikkan kesulitan tersebut hingga menjadi membaik.

\section{e. Ending}

Pada bagian ending seluruh penari melakukan gerak kesenian besepen yang mengungkapkan kegembiran masyarakat.
JOGED: Jurnal Seni Tari p-ISSN 1858-3989 | e-ISSN 2655-3171

\section{Konsep Garap Tari}

\section{Gerak Tari}

Pada dasarnya teknik gerak pada karya ini merupakan pijakan dari teknik gerak kais dan tepuk dalam tari Sepen.

\section{Penari}

Dalam karya tari ini membutuhkan penari yang berjumlah genap yang terdiri dari 5 penari perempuan dan 5 penari lakilaki, karena untuk mewakilkan makna kesuburan dan memudahkan dalam menata koreografi kelompok.

\section{Musik Tari}

Musik tari dalam karya ini merupakan musik yang dimainkan secara langsung yang berpijak dari musik Melayu dan digarap baru. Dari musik inilah memperkuat identitas dan spesifikasi karya tari ini yang berasal dari Daerah Belitung. Penata merencanakan untuk menggunakan instrumen musik seperti akordion, gambus, violin, gendang, babano, dan bass.

\section{Tata Rias dan Busana}

Penari perempuan dan penari laki-laki menggunakan rias wajah korektif. Baju yang digunakan penari perempuan adalah baju kebaya lama, berbahan dasar kain voal dan kombinasi goni, dengan model yang sederhana berfungsi untuk mempermudah penari saat 
JOGED: Jurnal Seni Tari

p-ISSN 1858-3989 | e-ISSN 2655-3171

bergerak. Baju yang digunakan penari laki laki berbahan sama juga dengan material baju perempuan, hanya saja model untuk penari laki-laki mempunyai kerah kecil.

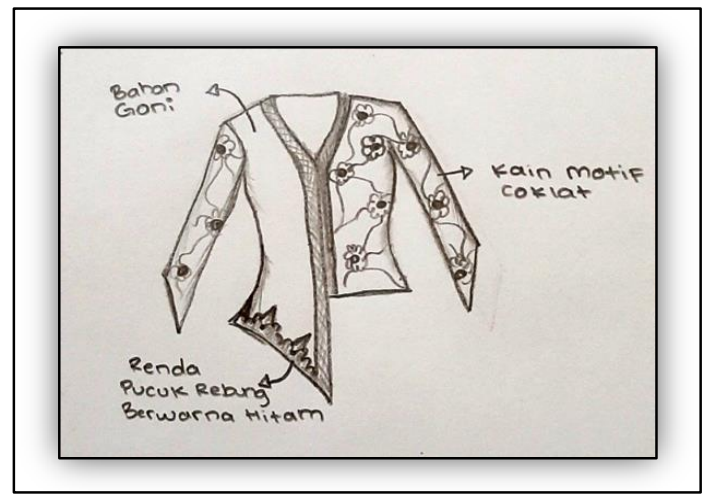

Gambar 5: Sketsa baju penari perempuan (Bella: 26 Maret 2020).

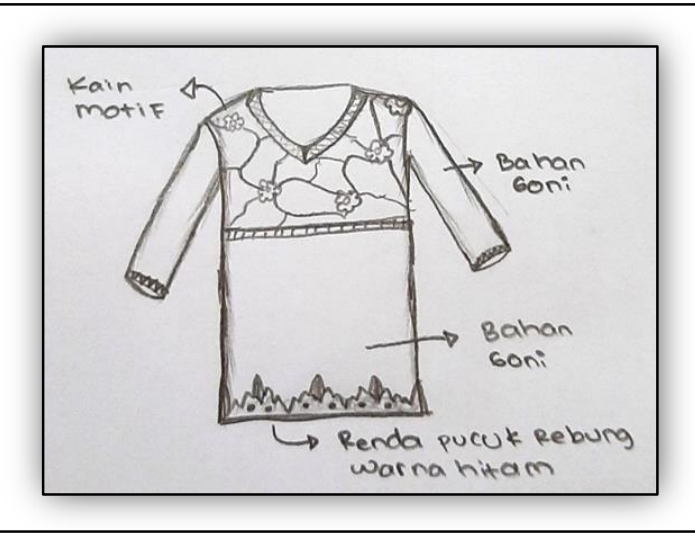

Gambar 6: Sketsa Baju penari laki-laki (Bella:26 Maret 2020)
LIGAS: KOREOGRAFI TENTANG PERJUANGAN PETANI TANAH TAMBANG DI BELITUNG

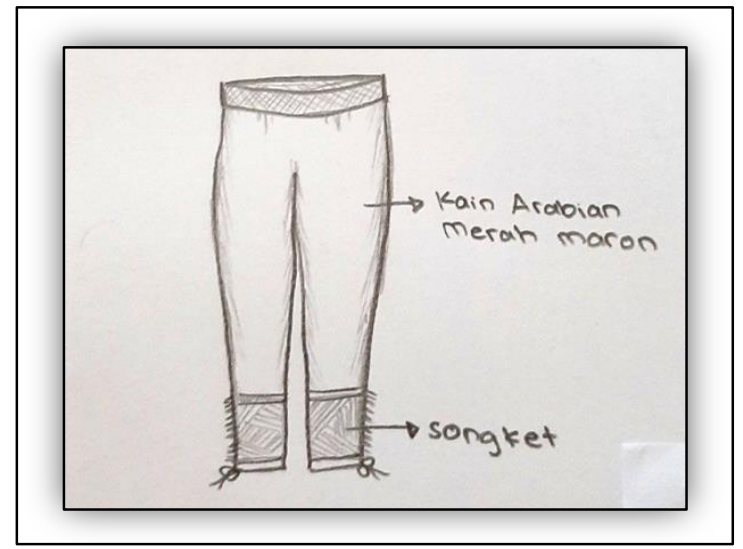

Gambar 7: Sketsa celana penari (Bella: 26 Maret 2020)

5. Pemanggungan

a. Tata Cahaya Panggung

Tata cahaya panggung merupakan bagian dari Tata Teknik Pentas yang spesifikasinya mengenai pengetahuan teori dan praktik membuat desain pencahayaan panggung. Tata cahaya mempunyai arti sebagai suatu metode atau sistem yang diterapkan pada pencahayaan yang didasari demi menunjang kebutuhan seni pertunjukan dan penonton. Sedangkan panggung berarti suatu tempat pertunjukan yang dipersiapkan bersama fasilitas perlengkapannya termasuk peralatan pencahayaan (Martono, 2015:1).

Pada bagian introduksi penata menggunakan elips profile untuk mendapatkan fokus di bagian down center stage atau aproon. Lalu adegan 1 penata menggunakan cahaya yang menyimbolkan kerja keras, dan bersemangat mengunakan filter seperti warna merah. Adegan 2 cahaya menjadi redup hingga membuat kesan yang kacau. Adegan 3 menggunakan pencahayaan umum 
LIGAS: KOREOGRAFI TENTANG PERJUANGAN PETANI TANAH TAMBANG DI BELITUNG

menyimbolkan suasana pertanian yang membaik. Dan ending menggunakan cahaya hangat berwarna merah untuk mendukung suasana kegembiraan pesta panen padi.

\section{b. Tata Rupa Pentas}

Pada karya tari ini, dibutuhkan setting panggung yaitu jaring paranet yang digantung, kemudian dijatuhkan ke panggung menyimbolkan ladang petani yang tercemar akibat pertambangan hingga petani menjadi kesusahan untuk bercocok tanam. Pertambangan adalah faktor utama yang membuat lahan pertanian menjadi kritis.

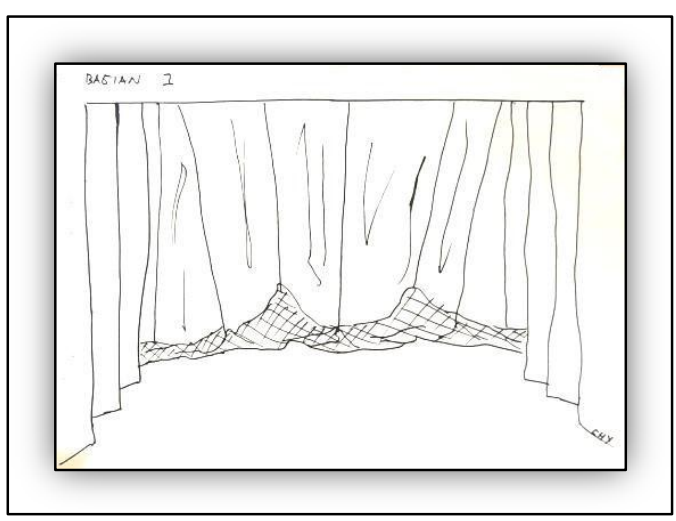

Gambar 8: Sketsa setting panggung adegan 1 (Cahyo: 10 Maret 2020).
JOGED: Jurnal Seni Tari p-ISSN 1858-3989 | e-ISSN 2655-3171

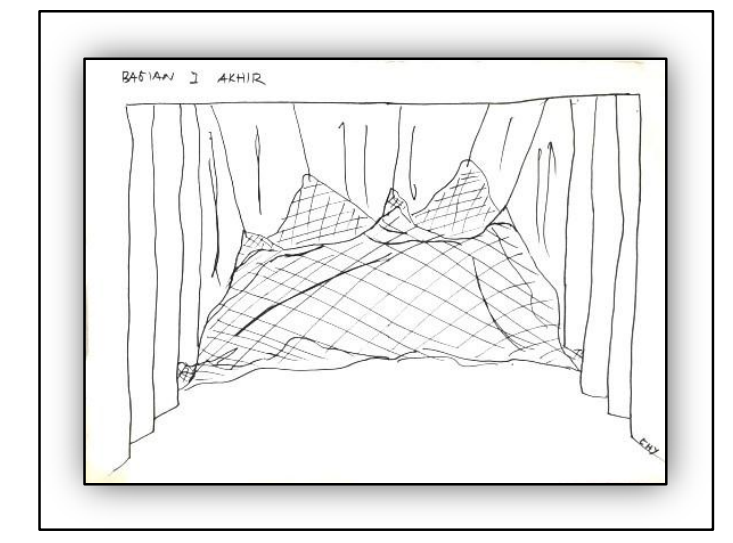

Gambar 9: Sketsa setting panggung adegan 1 akhir (Cahyo: 10 Maret 2020).

\section{Metode Penciptaan}

Dalam karya ini proses penciptaan diawali dari Ritus Bimasuci yang mencari jati diri dengan intropeksi, lalu dilanjutkan dengan Ritus meruang kemudian Ritus Tematik dan Ritus Kontemplasi. Di samping itu ada tahapan proses kreatif yang akan penata gunakan sebagai metode oleh Hendro Martono yaitu Sensasi Ketubuhan, Sensasi Emosi, sensasi Imaji, dan ritus ekspresi (Martono, 2012: 46).

1. Sensasi Ketubuhan

Sensasi ketubuhan merupakan proses mengamati objek, menyerap, dan menikmati secara mendalam, menjadikan sadar atas gejolak jiwa yang telah menyatu degan hal-hal yang ditangkap indrawi. Proses tersebut ditangkap oleh indrawi dari penglihatan, pendengaran, penciuman, sampai pengecapan. Penata melakukan penajaman penglihatan dengan cara pendekatan ke para petani langsung dan mengamati setiap gerak yang dilakukan petani (Martono, 2012: 62). 
JOGED: Jurnal Seni Tari

p-ISSN 1858-3989 | e-ISSN 2655-3171

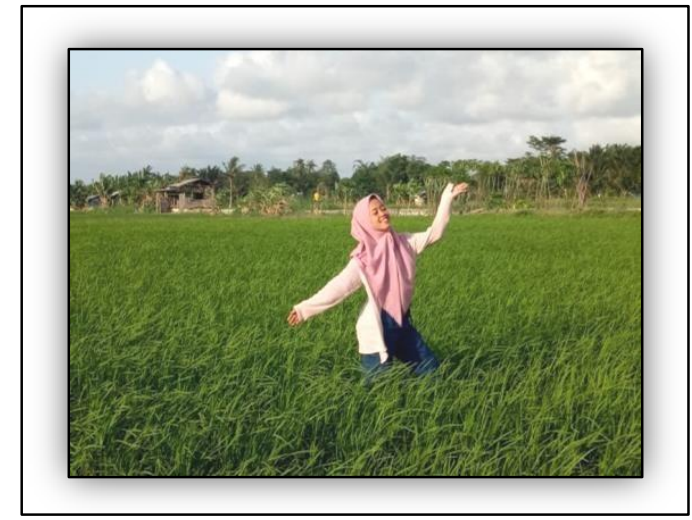

Gambar 10: Pose penata saat eksplorasi di sawah Air Serkuk (Foto: Bella, 14 Jan 2020).

Penata tari sangat dekat dengan lingkungan sekitarnya, yang terdapat tempat berladang dan bertambangan. Para petani ladang berusaha keras untuk bercocok tanam dengan kondisi tanah yang kering dan ditambah pertambangan sering membuat tanah menjadi asam akibat bahan kimia yang digunakannya. Area bekas tambang yang membentuk danau besar sehingga tidak bisa lagi digunakan untuk bercocok tanam, dan sering juga menjadi tempat yang menelan banyak korban terutama anak-anak yang tenggelam.

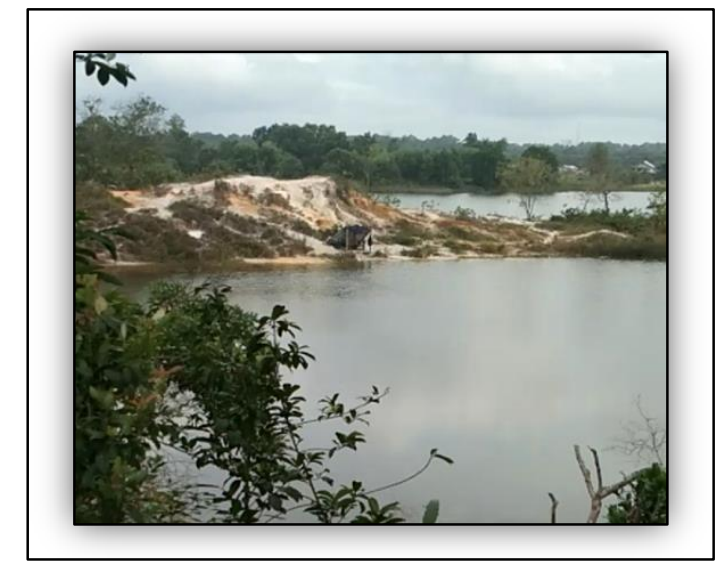

Gambar 11: Kondisi bekas tambang (Foto. Bella 4 Januari 2020 di Tanjung Pandan).
LIGAS: KOREOGRAFI TENTANG PERJUANGAN PETANI TANAH TAMBANG DI BELITUNG

2. Sensasi Emosi

Sensasi emosi merupakan proses lanjutan dari sensasi ketubuhan. Setelah penata melakukan pengamatan dan peladang di Belitung seperti kesedihan, ketakutan, hingga kegembiraan. Kesedihan tampak terlihat ketika petani mengalami gagal panen yang sangat besar hingga petani merugi. Faktor tersebut terjadi karena curah hujan yang tidak menentu dan rusaknya lahan karena pertambangan.

\section{Sensasi Imaji}

Dalam sensasi imaji merupakan kemampuan menemukan bayangan anganangan (ilusi) dan kemudian dituangkan ke dalam sebuah karya seni khususnya seni tari (Martono, 2012: 66). Penata membayangkan bumi Belitung indah dan asri ini seketika tenggelam karena ulah oknum yang tidak bertanggung jawab. Perusahan timah ilegal yang hanya mengambil keuntungan namun tidak bertanggungjawab untuk menutup kembali lubangan bumi yang sudah dikeruknya.

Penata memvisualkan kerusakan dan ketakutan penata akibat dampak pertambangan dengan menggunakan properti yaitu paranet berwana hitam yang biasanya digunakan sebagai atap peneduh dalam pertanian. Berimajinasi dari petani yang sedang berusaha keras untuk bercocok tanam dan tiba-tiba jatuhlah paranet hitam tersebut menutupi 
LIGAS: KOREOGRAFI TENTANG PERJUANGAN PETANI TANAH TAMBANG DI BELITUNG

seluruh petani. Lalu dengan posisi tertutup paranet penari bergerak menguasai ruang yang menyimbolkan pertambangan yang merajalela.

\section{Ritus Ekspresi}

Ritus ekspresi ditimbulkan dari suatu akumulasi rasa dan imaji yang ditransformasikan kegagasan gerak melewati pengalaman yang orisinil (Martono: 2012: 67). Penata mulai merangkai motif gerak dan mengkoreografikan dari hasil sensai ketubuhan, sensasi emosi, dan sensasi imaji. Ditemukan gerak-gerak yang sesuai dengan apa yang dirasakan tepat dalam mewakili suasana hati petani ladang di Belitung. Gerak yang digunakan dalam karya ini yaitu gerak simbolis dan representasional. Dari petani membuka ladang, mengolah tanah, bercocok tanam, terjadinya kerusakan hingga tarian Sepen.

\section{E. Tahapan Penciptaan}

Tahapan penciptaan terbagi menjadi 2 yaitu tahapan awalan dan tahapan lanjut:

1. Tahap Awal

\section{a. Penetapan Konsep}

Konsep dalam karya tari ini adalah makna yang terkandung dari gerak kais dan tepuk di tari Sepen. Makna gerak kais adalah mencari rezeki, dan tepuk tangan merupakan ungkapan kegembiraan. Setiap tahunnya masyarakat Belitung selalu melaksanakan Upacara adat Marastahun sebagai upacara selamat kampung dan pesta panen padi.
JOGED: Jurnal Seni Tari p-ISSN 1858-3989 | e-ISSN 2655-3171

Walaupun di tahun 2019 terjadi gagal panen terbesar masyarakat Belitung tetap melaksanakan acara pesta panen padi tersebut dengan penuh suka ria. Hal tersebut menjadi konsep dalam karya Ligas ini. Kesusahan dan kegagalan yang petani Belitung alami tidak memutuskan semangat petani di sana. Dari faktor cuaca seperti kemarau dan dampak dari pertambangan menjadi rintangan yang dilalui petani.

\section{b. Pemilihan dan Penetapan}

\section{Penari}

Penari berjumlah genap dan berpasangpasangan, terdiri dari penari laki-laki dan penari perempuan dengan kriteria mempunyai kelenturan tubuh yang mudah mengikuti gerak tari apapun, memiliki daya ingat menghapal gerak yang baik, dan mempunyai waktu untuk berlatih dalam proses penggarapan karya. Penari dalam karya ini adalah Ezha, Erico, Rizki, Rahma, Huda, Nanda, Rendy, Febby, Pebri, dan Anggit.

\section{c. Penetapan Komposer}

Penata musik adalah Rendy Oka Trinada. Ia mempunyai basic Melayu Belitung, dan berasal dari Tanjung Pandan. Ada kedekatan asal dengan penata musik sehingga dirasa cocok untuk kembali bekerja sama, karena sebelumnya ia juga yang 
JOGED: Jurnal Seni Tari

p-ISSN 1858-3989 | e-ISSN 2655-3171

menggarap musik ketika ujian koreografi tunggal, dan ujian koreografi

mandiri.

\section{d. Pencarian Gerak}

Penata melakukan pencarian gerak dengan menggunakan ritus ekspresi. melakukan eksplorasi dilakukan dengan menggunakan tongkat kayu sebagai properti tari. Hal ini terus diulangi dan dicoba sambil membayangkan menjadi seorang peladang yang bekerja keras untuk bercocok tanam.

\section{Tahap Lanjut}

Tahap lanjut adalah proses latihan yang dilakukan bersama penari. Proses ini dimulai dari tanggal 4 Februari 2020. Penata menggarap bagian introduksi yang terfokus pada dua penari.

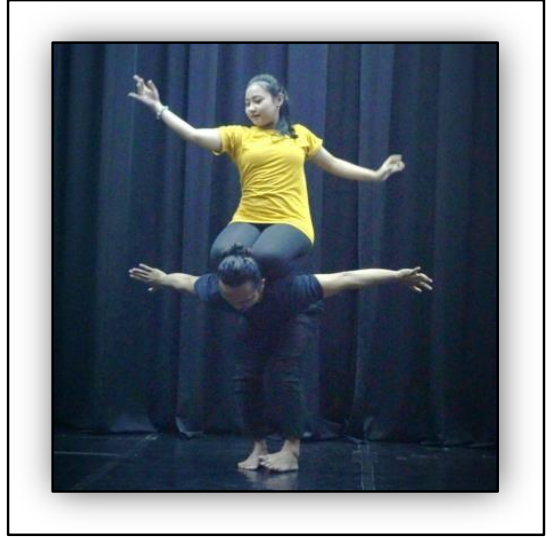

Gambar 12: Pose adegan introduksi pada seleksi 2 (A'a Ari: 07 Maret 2020)

Pada tanggal 13, 15, 19 Februari 2020 penata mengintruksikan penari dengan imajinasinya sendiri-sendiri, mengandaikan menjadi petani ladang dari membuka hutan hingga mengolah

\section{LIGAS: KOREOGRAFI TENTANG PERJUANGAN} PETANI TANAH TAMBANG DI BELITUNG

tanah. Setalah itu penata langsung memberikan gerak rampak dan juga pola permainan igal. Memvisualkan kerja keras petani yang sedang berladang.

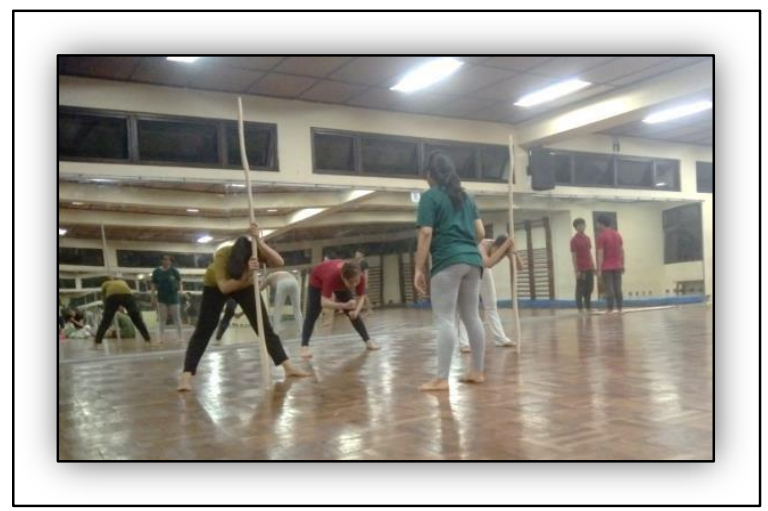

Gambar 13: Latihan bersama penari di studio 2 (Bella: 19 Februari 2020).

Pada tanggal 20 Februari 2020 pukul 17.00 WIB mempresentasikan gerak kepada dosen pembimbing 1. Setelah presentasi dilanjutkan dengan eksplorasi jaring-jaring hitam sebagai simbol gerak kerusakan akibat tambang.

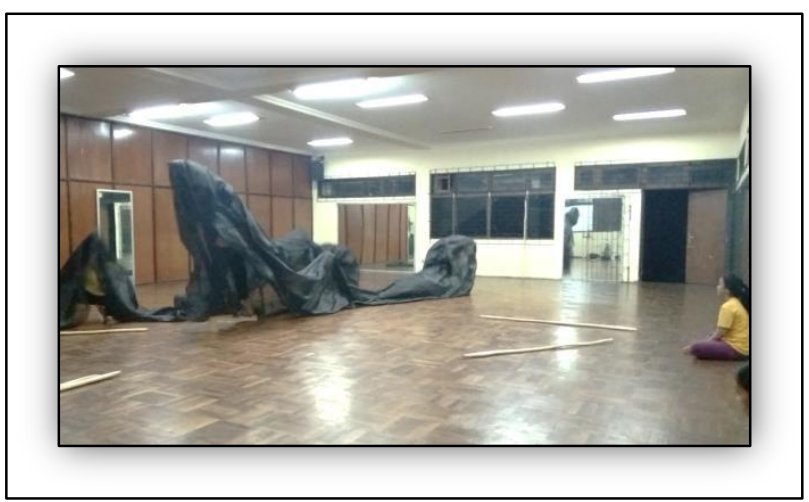

Gambar 14: Eksplorasi jaring-jaring hitam yang menyimbolkan keterpurukan petani yang ditimpa oleh kerusakan lingkungan, di studio 1 (Bella: 20 Februari 2020).

Pada tanggal 18 dan 19 Maret 2020 merupakan latihan terakhir. Hal tersebut merupakan dampak dari pandemic virus covid19 yang terjadi hingga ke Indonesia. Melihat situasi yang semakin memburuk, penata 
LIGAS: KOREOGRAFI TENTANG PERJUANGAN PETANI TANAH TAMBANG DI BELITUNG

mengambil keputusan untuk menunda proses latihan bersama dengan seluruh pendukung karya Ligas, semakin hari semakin banyak merenggut korban. Namun proses kreatif tetap berjalan terus, dari menyelesaikan catatan tari, membuat pola lantai, menambahkan referensi buku, video, dan wawancara ke masyarakat Belitung hingga semuaya terselesaikan dengan tuntas.

\section{B. Hasil Penciptaan}

Hasil penciptaan dalam karya Ligas merupakan hasil penciptaan keseluruhan dari proses awal penciptaan hingga tahapan seleksi 2. Hal yang sangat perlu diketahui adalah proses Penciptaan Tugas Akhir Jurusan Tari ISI Yogyakarta Strata-1 terhambat akibat datangnya Virus Covid-19. Masa Pandemi yang dialami, membuat seluruh masyarakat saling menjaga jarak, tidak mengadakan perkumpulan, dan tetap di rumah saja. Proses kreatif selama 1 bulan atau 11 kali pertemuan dalam karya Ligas ini berhasil tergarap menjadi sebuah koreografi tari utuh dengan durasi 17.05 menit, walaupun tidak bisa dipentaskan.

\section{Struktur Tari}

Secara tekstual tari dianalisis dari sisi struktur, bentuk, estetis koreografis, sedangkan kajian kontekstual melihat fenomena tari yang lebih menekankan pada perpektif sosialbudaya, sehingga telaah bentuk (stuktur) nya
JOGED: Jurnal Seni Tari p-ISSN 1858-3989 | e-ISSN 2655-3171

akan mengupas tari sebagai simbol yang dikaitkan dengan masyarakat (Martiara-Astuti, 2018: 10).

\section{a. Introduksi}

Adegan introduksi terdapat penari lakilaki dan perempuan yang berdampingan namun pada akhirnya mereka bertentangan. Fokus yang terjadi dari penari perempuan yang duduk bersimpuh di atas penari laki-laki, yang memiliki simbol penari perempuan adalah kesuburan dan penari laki-laki adalah tanah yang merupakan tempat tanaman tumbuh, lalu akhirnya menyerang penari perempuan sebagai simbol kerusakan lingkungan yang terjadi di Belitung akibat tambang.

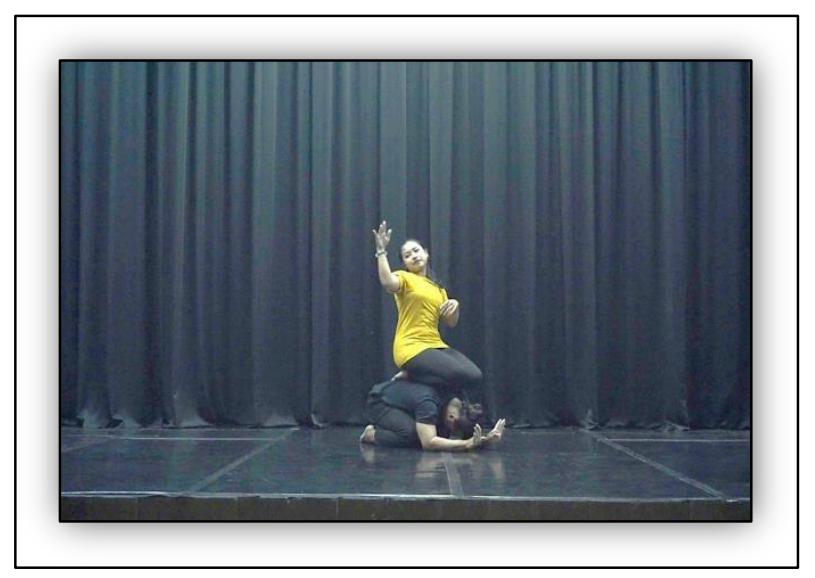

Gambar 15: Pose adegan introduksi pada Seleksi 2 (A'a Ari: 07 Maret 2020)

\section{b. Adegan 1}

Pada adegan 1 diawali dengan suasana tenang, menggambarkan aktivitas petani yang masuk dan membuka hutan untuk bercocok tanam. Seluruh penari menggunakan properti 
JOG5D: Jurnal Seni Tari

p-ISSN 1858-3989 | e-ISSN 2655-3171

igal untuk melubangi tanah untuk menyemai bibit padi.

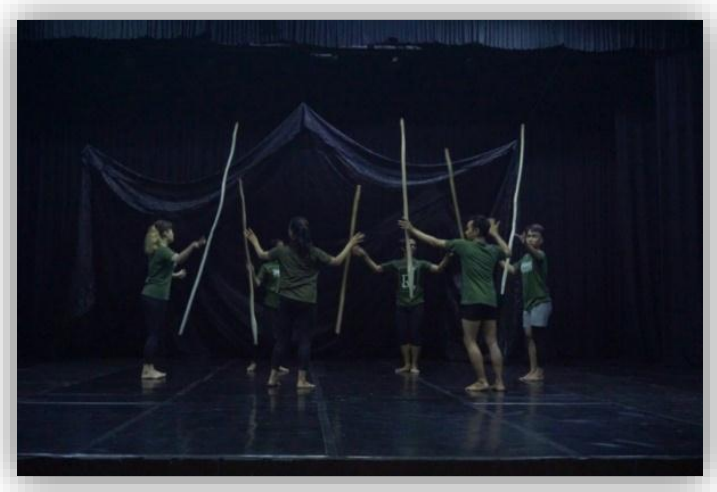

Gambar 16: Adegan 1 simbol gerak kerjasama pada saat Seleksi 2.

\section{c. Adegan 2}

Pada adegan 2 ini, penari menggunakan properti jaring-jaring paranet hitam berukuran besar yang menutupi seluruh tubuh penari. Jaring-jaring tersebut menyimbolkan kerusakan lingkungan yang diakibatkan dari pekerja tambang. Penari bergerak menggeliat-liat menyimbolkan tanah yang tidak subur menjadi menyebar hingga ke berbagai arah. Hingga suasana mencekam, terikat, dan tegang terproyeksikan ke penonton.

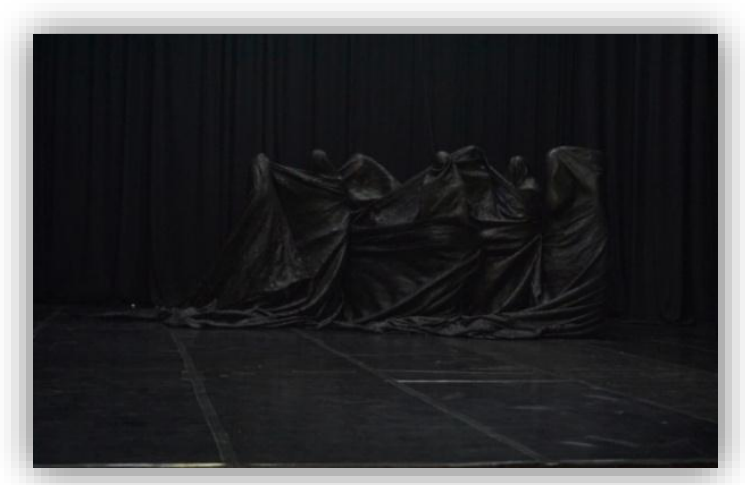

Gambar 17: Adegan 2 pada saat Seleksi 2 (A'a Ari: 07 Maret 2020).
LIGAS: KOREOGRAFI TENTANG PERJUANGAN PETANI TANAH TAMBANG DI BELITUNG

\section{d. Adegan 3}

Adegan 3 merupakan penggambaran para petani yang telah tertimpa musibah perlahan bangkit dari keterpurukan dan berusaha sekuat tenaga membalikkan keterpurukan tersebut menjadi kegembiran. Teknik geraknya adalah mengalir dengan tempo yang lambat.

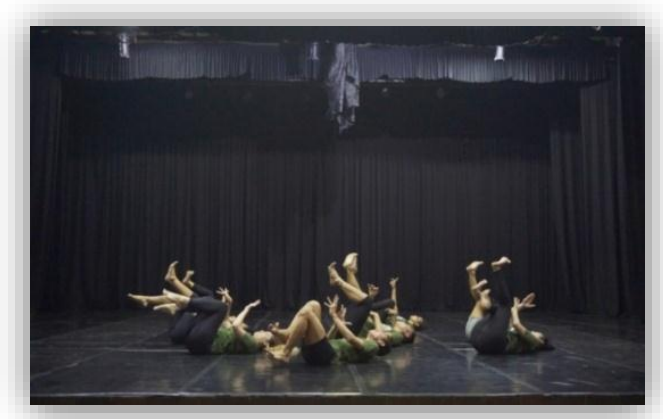

Gambar 18: Adegan 3 pada saat Seleksi 2 (A'a Ari: 07 Maret 2020).

\section{e. Ending}

Pada bagian ending ini memiliki suasana bergembira menyimbolkan pesta panen padi yang setiap tahunnya selalu diselenggarakan di Kab.Belitung. Motif gerak yang digunakan adalah 3 motif gerak sepen seperti sepen biase, sepen silang, dan sepen yasek yang kemudian divariasikan dan dikembangkan. 
JOGED: Jurnal Seni Tari p-ISSN 1858-3989 | e-ISSN 2655-3171

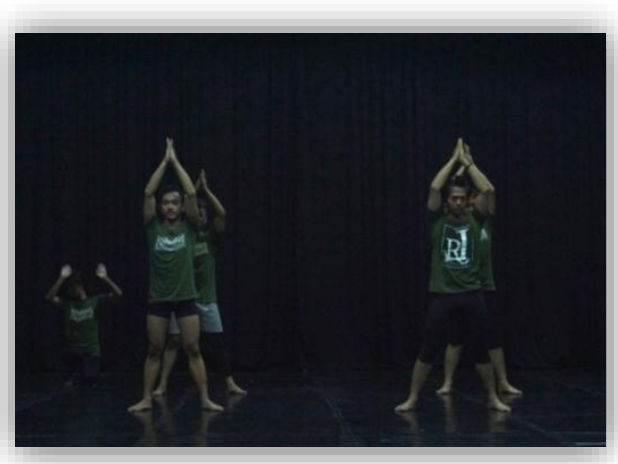

Gambar 19: Bagian Ending pada saat Seleksi 2 (A'a Ari: 07 Maret 2020)

\section{Motif Gerak Tari dari karya Ligas}

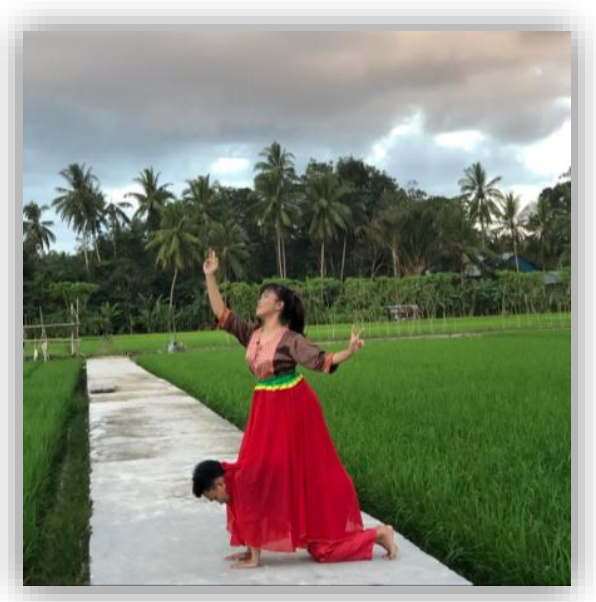

Gambar 20: Pose motif betumbo, lokasi sawah air serkuk (Bella: 22 Juni 2020)

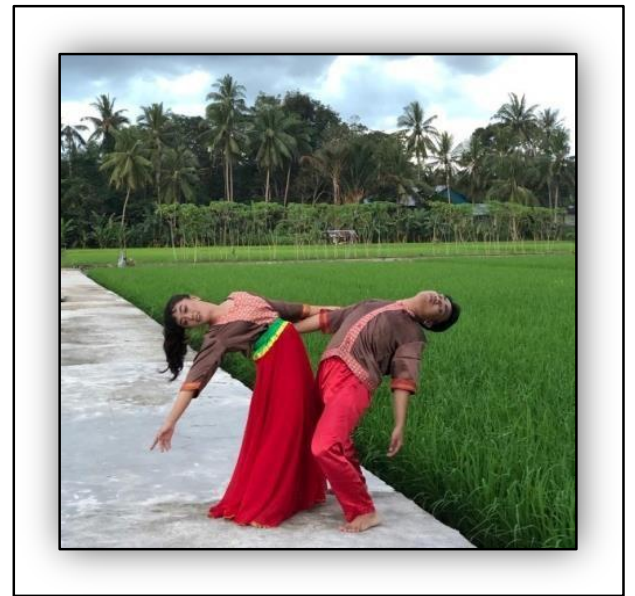

Gambar 21: Pose motif bersatu antara penari laki-laki dan perempuan. Air serkuk (Bella: 22 Juni 2020).

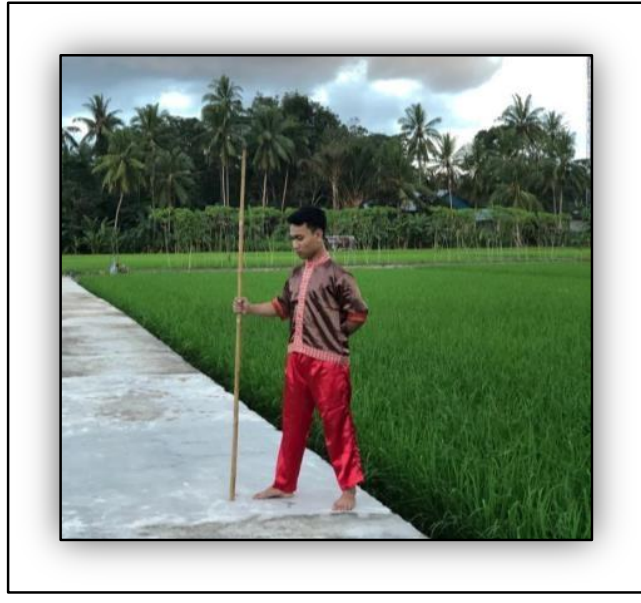

Gambar 22: Pose motif nugal dengan menggunakan properti igal, Air serkuk (Bella: 22 Juni 2020).

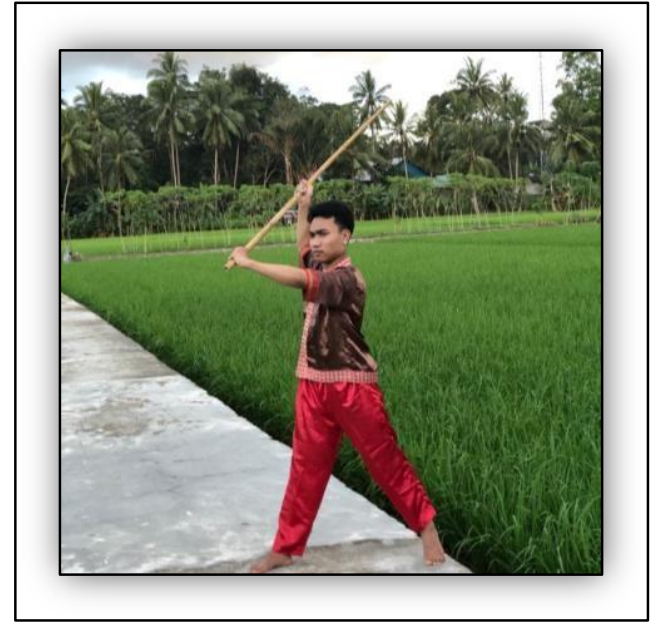

Gambar 23: Pose motif gerak ngelibat, lokasi sawah Air serkuk (Bella: 22 Juni 2020).

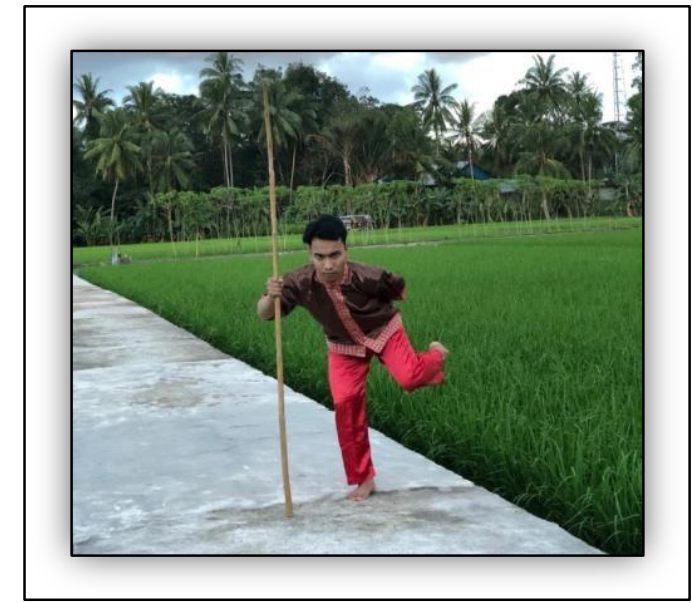

Gambar 24: Pose motif gerak bekais, Air serkuk(Bella: 22 Juni 2020). 
JOGED: Jurnal Seni Tari

p-ISSN 1858-3989 | e-ISSN 2655-3171

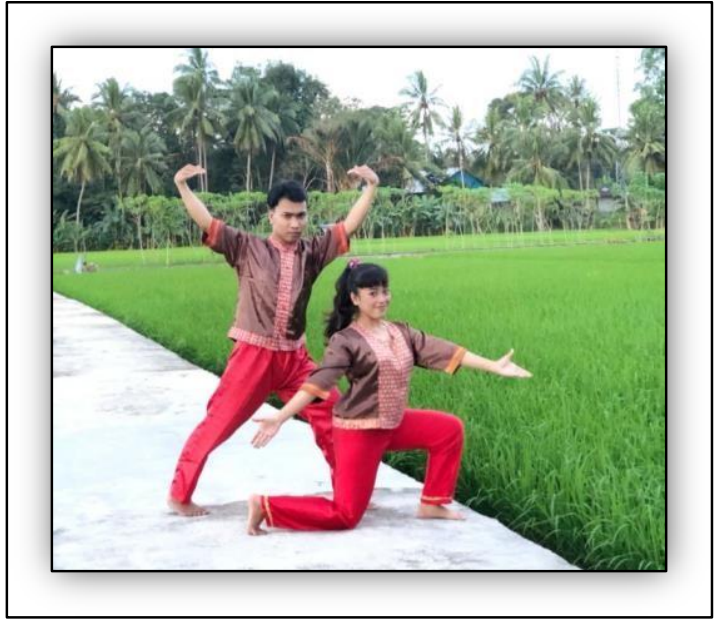

Gambar 25: Pose motif gerak mereka, Lokasi sawah air serkuk (Bella: 22 Juni 2020).

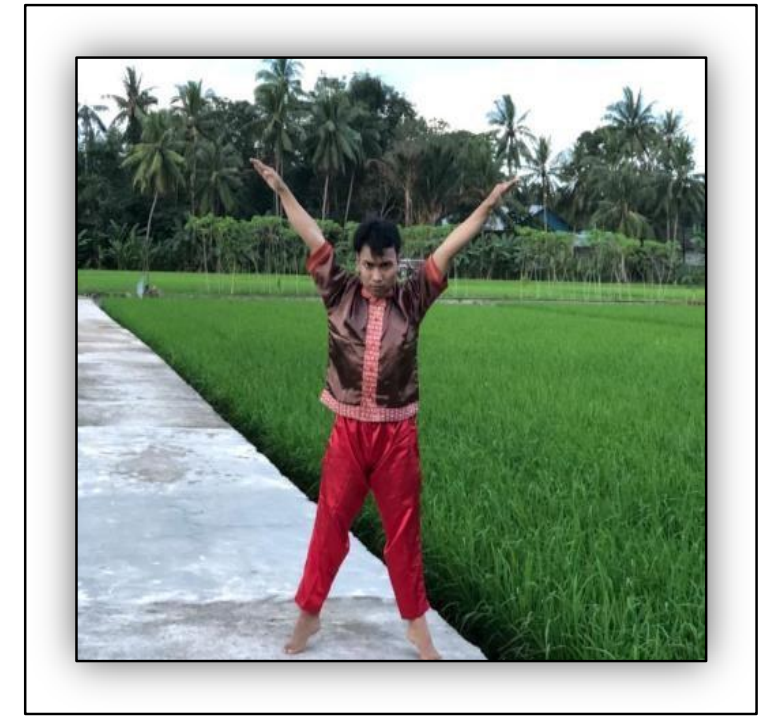

Gambar 26: Pose motif gerak tusok luncat, Air serkuk (Bella: 22 Juni 2020).

\section{Rias Penari}

Dalam karya Ligas menggunakan rias wajah bold, yang identik dengan permaianan warna berani, tegas, dan lebih tebal. Rias tersebut menampilkan kesan pandangan tajam dan tegas, sehingga penonton dapat melihat ekspresi penari dengan jelas walaupun dari kejauhan. Rias tersebut juga mengindari wajah

\section{LIGAS: KOREOGRAFI TENTANG PERJUANGAN} PETANI TANAH TAMBANG DI BELITUNG

penari yang pucat akibat cahaya lampu yang menerangi di atas panggung.
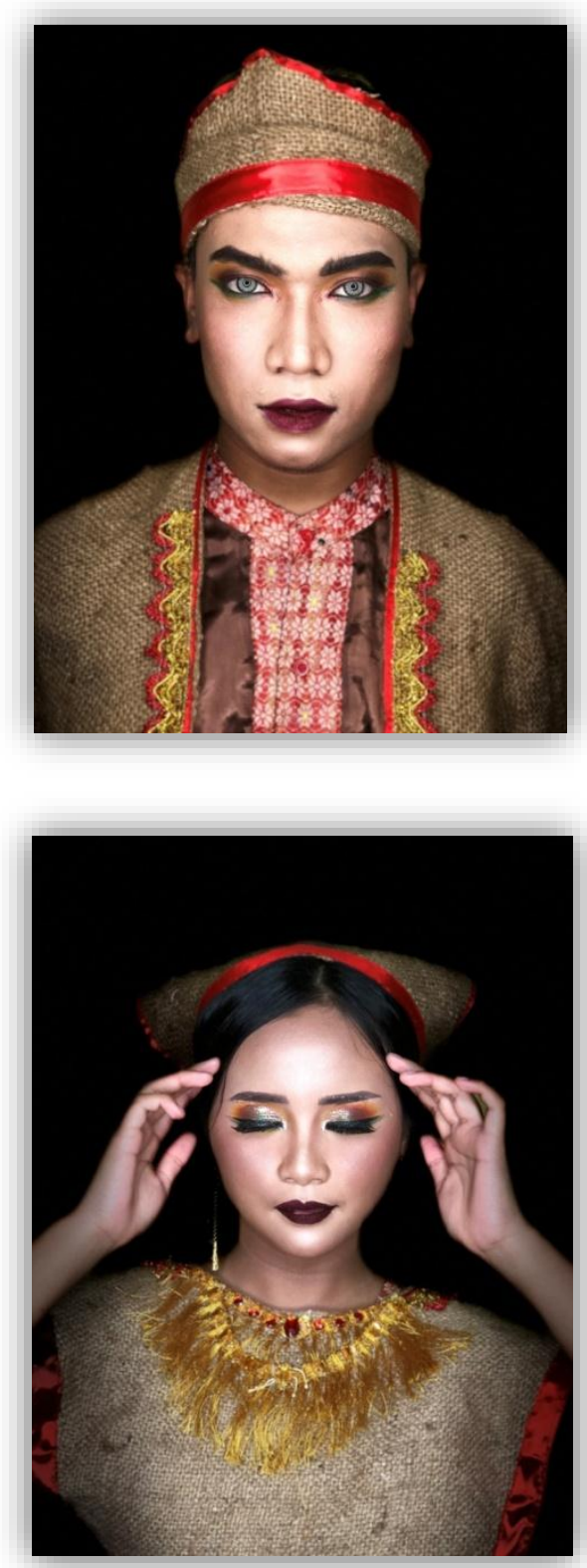

Gambar 27.28: Rias wajah bold untuk penari laki-laki dan perempuan (Akbar, 6 juli 2020) 
LIGAS: KOREOGRAFI TENTANG PERJUANGAN PETANI TANAH TAMBANG DI BELITUNG

\section{Busana Penari}

Busana yang digunakan juga terkesan sangat ramah lingkungan karena menggunakan goni yang terbuat dari serat tumbuhan.

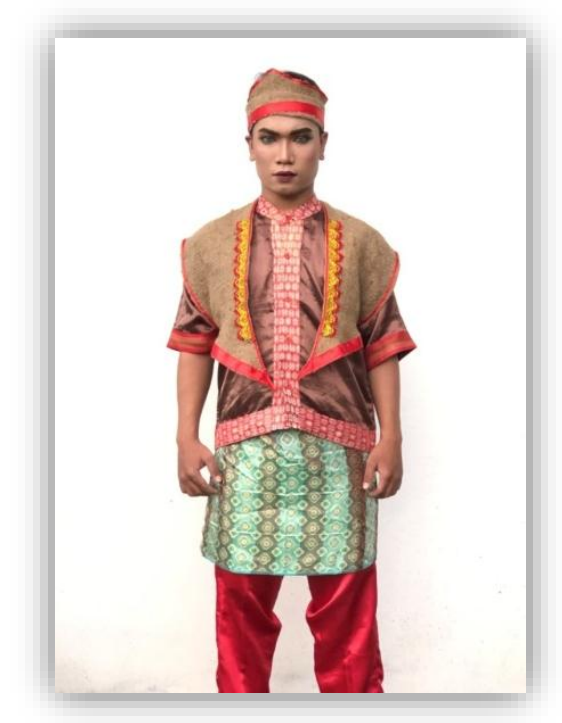

'Gambar 29: Busana penari tampak depan laki-lak

(Akbar, 6 Juli 2020)

Penari laki-laki menggunakan baju lengan pendek yang berwarna coklat. Baju tersebut berbalut kain songket pada bagian list kedua lengan baju, kerah baju, dan kancing baju. Lalu dipadukan dengan rompi yang terbuat dari bahan goni. Bawahan untuk penari laki-laki menggunakan celana panjang berwarna merah dan divariasi songket hijau kekuningan.

Penari perempuan menggunakan baju lengan 7/8 yang berwarna coklat. Kemudian menggunakan rompi yang terbuat dari goni dan di tamba variasi bulu-bulu emas yang ada di pinggiran leher. Bawahan untuk penari perempuan pada adegan 1 dan adegan 2 menggunakan celana panjang berwarna merah,
JOGED: Jurnal Seni Tari p-ISSN 1858-3989 | e-ISSN 2655-3171

lalu pada adegan 3 dan ending menggunakan rok merah 7/8, yang membuat kesan penampilan menjadi feminim.

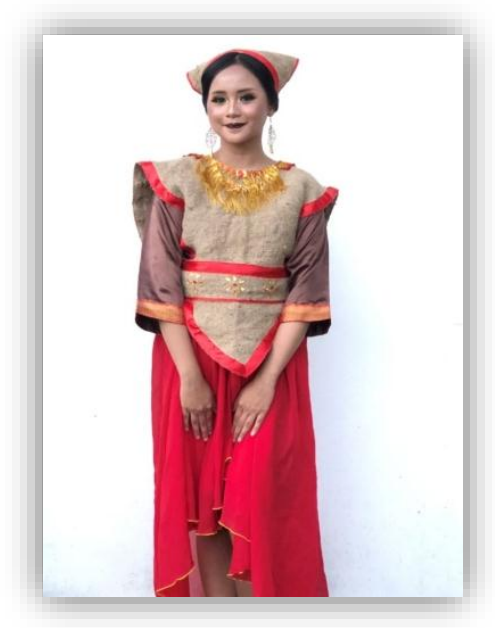

Gambar 30: Busana penari perempuan tampak depan (Akbar, 6 Juli 2020)

\section{PENUTUP}

Karya Ligas adalah karya tari yang terinspirasi dari pengamatan terhadap keadaan agraris masa kini di daerah Belitung. "Ligas" artinya berusaha sekuat tenaga sebelum kehilangan semuanya. Situasi yang miris akibat kurang suburnya tanah di Belitung membuat petani harus berusaha lebih keras. Bermula dari aktivitas petani ladang yang sedang bercocok tanam, simbol kesuburan, hingga terjadi suasana kemarau dan kondisi kerusakan lingkungan akibat pertambangan yang penata visualkan dalam karya ini. Landasan penciptaan karya tari ini menggunakan gerak mengais yang bersumber dari gerak spesifik tari sepen yang menyimbolkan mencari rezeki di ladang, dan kemudian gerak menugal. 
JOGED: Jurnal Seni Tari

p-ISSN 1858-3989 | e-ISSN 2655-3171

\section{DAFTAR SUMBER ACUAN}

\section{A. Sumber Tercetak}

Dana, I Wayan. 2016. Potret Sanggar-Sanggar

Seni Sebagai Pusat Dan Wadah Pengembangan Kesenian Belitung.

Yogyakarta: Kepel Press.

Fitrorozi. 2017. Pedoman Standart Tari Selamat Datang Kabupaten Belitung, Tanjungpandan: Dinas Pendidikan Dan Kebudayaan Kabupaten Belitung.

Hadi, Y.Sumandiyo. 2003. Aspek-Aspek Dasar Koreografi Kelompok, Yogyakarta:Elkapi.

Hadi, Y.Sumandiyo. 2007. Kajian Tari Teks dan Konteks, Yogyakarta: Pustaka Book Publisher.

Hadi, Y. Sumandiyo. 2016. Koreografi: Bentuk - Teknik - Isi, Yogyakarta: Cipta Media (edisi Revisi).

Hadi, Y. Sumandiyo. 2017. Koreografi Ruang Prosenium, Yogyakarta: Cipta Media (Cetak Pertama).

Junaedi, Deni. 2017. ESTETIKA Jalani Subjek, Objek, dan Nilai.Yogyakarta: ArcTV

Martiara, Rina dan Budi Astuti. 2018. Analisis Struktural Sebuah Metode penelitian Tari. Yogyakarta: Badan Penerbit ISI Yogyakarta.

Smith, Jacqueline M. 1976. Dance Composition: A Practical Guide of Teacher, diterjemhkan oleh Ben Suharto 1985

Komposisi Tari Sebuah Petunjuk Praktis Bagi Guru. Yogyakarta : Ikalasti.

Sumardjo, Jakob. 2006. Estetika Paradoks. STSI Bandung: Sunan Ambu Press.
LIGAS: KOREOGRAFI TENTANG PERJUANGAN PETANI TANAH TAMBANG DI BELITUNG

Martono, Hendro. 2015. Mengenal Tata cahaya Seni Pertunjukan. Yogyakarta: Cipta Media

Martono, Hendro. 2012. Ruang Pertunjukan dan Berkesenian. Yogyakarta: Cipta Media

Miroto, Martinus. 2014. Pertunjukan Realitas Teleholografis Body In Betwen: Tubuh di Antara Maya dan Nyata. Distertasi Institut Seni IndonesiaYogyakarta.

Yudiaryani, et.al (editor). 2017. Karya Cipta Seni Pertunjukan. Yogyakarta: JB Publisher.

\section{B. Sumber Lisan:}

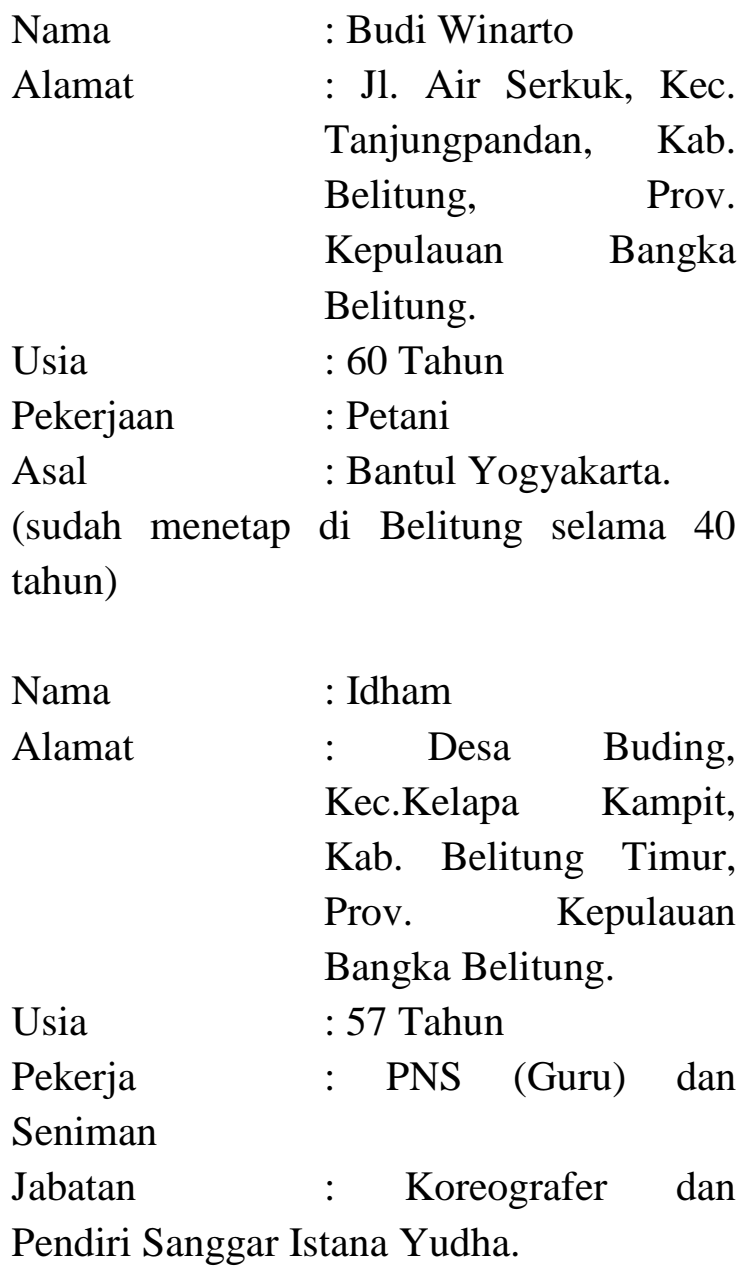




$\begin{array}{ll}\text { Nama } & \text { : Suchron } \\ \text { Alamat } & : \quad \text { Jl. Stadion, } \\ & \text { Pangkalalang, } \\ & \text { Kec.Tanjungpandan, } \\ & \text { Kab. Belitung, Prov. } \\ & \text { Kepulauan Bangka } \\ & \text { Belitung. } \\ \text { Usia } & : \text { 63 Tahun } \\ \text { Pekerjaan } & : \text { PNS (Guru }) \text { dan } \\ \text { Seniman } & \text { Kabatan } \\ \text { Pemilik Sanggar Pelandok Laki. }\end{array}$

Nama : Wulan Febriyanti

Alamat : Jl. Air Serkuk, Kec. Tanjungpandan, Kab. Belitung, Prov. Kepulauan Bangka Belitung.

Usia : 31 Tahun

Pekerjaan : PNS (Guru) dan Seniman

Jabatan : Koreografer dan Pemilik Sanggar Seni Wulan Menari.

\section{Webtografi:}

https://www.google.com/amp/s/bangka tribunnews.com/amp/2019/09/13/gaga 1-panen-padi-mencapai-rp-2-m-klaimasuransi-petani.

https://kebudayaan.kemdikbud.go.id/di $\underline{\text { twdb/maras-taun. }}$.

https://disbudpar.belitungtimurkab.go.i $\mathrm{d} /$ content/mengenal-sepen-budingpotensi-wisataibudaya-di-belitung$\underline{\text { timur }}$

https://Youtu.be/uN7ljzUXqq8 "Tari Sepen (Bangka Belitung, Sumbagsel)" . https://www.google.com/amp/s/www. mongabay.co.id/2019, oleh Nopri Ismi.

https://m.tribunnews.com/regional/201 4/02/19/polda-babel-akan-berantaspenambang-liar

https://Youtu.be/uN7ljzUXqq8, oleh Rizki Purnama dipublikasi pada tanggall 21 April 2015.

https://youtu.be/NArFdcM4uMc dipublikasi pada tanggal 24 Oktober 2017.

\section{Diskografi}

Video tari Begencak, karya Bella Asmanabillah.

Video tari Sepen oleh sanggar Dian Praja, Pembukaan Festival Desa Wisata Belitung 2019.

Video Songs Of The Wanderers Cloud Gate Dance Theater. 